\title{
An Analysis of Capacity Market Mechanism for Solar Photovoltaics in France
}

\author{
Manjola Banja*», Martin Jégard** \\ *Independent Consultant, Former Scientific Officer, Energy Efficiency and Renewables Unit, JRC, EC, Ispra, Italy \\ **PhD Student, Former Trainee, Energy Efficiency and Renewables Unit, JRC, EC, Ispra, Italy \\ (m.banja@yahoo.com,$\underline{\text { martin.jegard@gmail.com })}$ \\ $\$$ Corresponding Author; Manjola Banja, Via Piave 15, Varese, Italy, Tel: +393299162476, \\ m.banja@yahoo.com
}

Received: 25.12.2018 Accepted:03.03.2019

\begin{abstract}
The energy policy in France that focuses on energy transition and reduction of greenhouse gases, has provided favourable conditions for the deployment of solar photovoltaics. In September 2018 more than $80 \%$ of the expected plan of solar photovoltaics capacity for this year was reached. After 2010 the support for solar photovoltaics in France took the form of capacity market mechanism. This paper aims to provide insight to this shift that brought the highest additional installed capacity of solar photovoltaics in France. The objective of this paper is to provide an indicative analysis on how the capacity market mechanism for solar photovoltaics in France has changed over years and how administrative procedures related to this mechanism have been improved. The analysis shows that this system has been favourable to small scale producers even that lately a tendency is seen to move towards large-scale projects. The system has seen a high level of competition, especially between ground-mounted projects, oversubscribing the required volume with more than 12 times. For each MW solar photovoltaics required through calls for tender, 3.5 MW were offered by the submitted dossiers. We found that in 2017 the average price of tenders for solar photovoltaics almost halved compared with the level this indicator had in 2011. For ground mounted solar photovoltaics projects, the prices decreased by $72 \%$. For rooftop installations the decrease accounted for $60 \%$. Despite the improvements done in administrative procedures, still some barriers are in place influencing the speed of the deployment of solar photovoltaics technology in France.
\end{abstract}

Keywords solar photovoltaic, capacity mechanism, administrative procedures, competition level, costs.

\section{Introduction}

Policies in energy and environmental protection are very crucial in many countries [1]. The attention towards solar photovoltaics (PV) today is considerable, due to the potential that this technology has in the deployment of renewable energy [2]. Understanding the role of support schemes in the deployment of renewable technologies as solar PV, is a relevant and actual topic in both global and European energy context [3]. The EU adopted in 2013 a guidance document to support its Member States for the designing and reforming renewable energy support schemes [4]. Further changes were implemented from 2014 when the European Commission introduced its "Guidelines on State Aid for Environmental Protection and Energy" [5]. These Guidelines set the general conditions for investments and operating aid for any features of new RES support schemes through 2020.

On 24 December 2018 the revised Renewable Energy Directive (RED II) [6] establishes a binding EU target of at least $32 \%$ for 2030 with a review for increasing this figure in 2023. The RED II states "Market-based mechanisms, such as tendering procedures, have been demonstrated to reduce support cost effectively in competitive markets in many circumstances. However, in specific circumstances, tendering procedures may not necessarily lead to efficient price discovery. Balanced exemptions may therefore need to be considered to ensure cost-effectiveness and minimise overall support cost". Article 4(2) of the same directive states "Support schemes for electricity from renewable sources shall provide incentives for the integration of electricity from renewable sources in the electricity market in 
a market-based and market-responsive way, while avoiding unnecessary distortions of electricity markets as well as taking into account possible system integration costs and grid stability". Different energy policies and public support programs for renewable energies, as well as the different grades of liberalization of their domestic electricity markets are applied in EU countries bringing to different EU market conditions for photovoltaics [7].

France keeps now the fourth position among EU countries regarding to the deployment of solar PV, having also installed the largest EU photovoltaics system. France plans to install $10.2 \mathrm{GW}$ solar PV in 2018 and $30 \mathrm{GW}$ between 2020 and 2035. France presented its long-term climate action plan under the Paris Agreement end of 2016. The country set a $40 \%$ target reduction in emissions by 2030 compared to 1990 and a $75 \%$ reduction by 2050 compared to 1990. To meet this target, France needs to cut 9-10 Mt of $\mathrm{CO}_{2}$ every year.

This paper aims to provide an analysis of the capacity market mechanism implemented in France to support the deployment of solar PV. The paper is structured to provide a short overview of support system for renewables in France, a description of tendering system for solar PV, a description of the improvements of administrative procedures for the removal of regulatory and non-regulatory barriers, a short section of solar PV costs in Europe and France and some empirical findings from the shift towards capacity market mechanism in France.

\section{Support system for renewables in France}

The Electricity Law of 2000 [8] set the level of first feed-in tariffs in France. It regulated the free access to the grid of French energy producers. Since 2000 the number of technologies eligible under the French national feed-in tariff mechanisms has increased over time. The increased number of renewable technologies under the feed.in tariff scheme showed ambitiousness of French Government multiannual plans, mainly for electricity sector. France's national plans/targets have been set also in the light of EU renewable energy directives of 2001 and 2009. The feed-in tariff mechanism operated with only technology-specific programsize caps. The Energy Code (2011) consolidated the French energy framework composed by several decrees and orders that implements the support schemes for the deployment of renewables [9].

The new organisation of the electricity market was done through the Law No. 2010/1488 of December 2010 [10] which established the Regulated Access to the Historical Nuclear Electricity (ARENH). Under this regulation to the alternative suppliers it was given an access to nuclear electricity in order to sell it to end consumers. The law ended the regulated tariffs for industrial consumers [11]. Law No. 2015/992 (the Energy Transition for Green Growth) sets out the reform of the feed-in tariff (FIT) support scheme, its funding towards a market premium and calls for tender for large-scale mature renewable facilities.

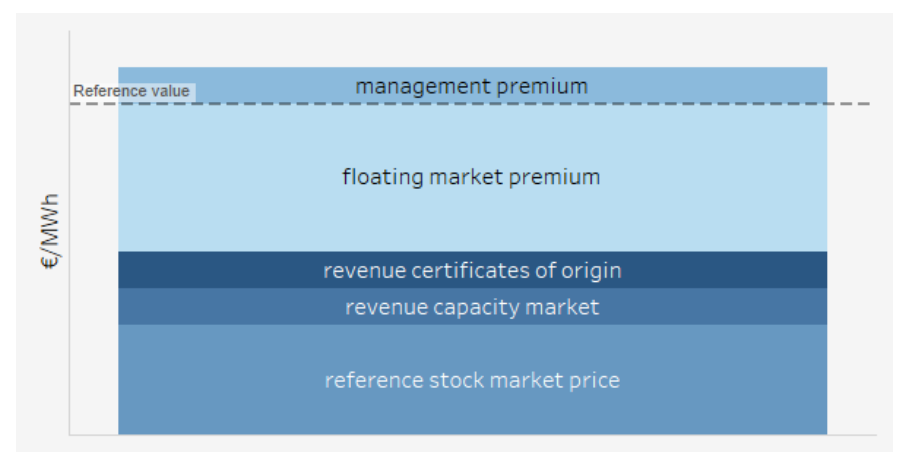

Fig. 1. Additional remuneration scheme in France

The law aimed to ensure the cost-competitiveness of renewable energies defining that FITs contracts are exceptional, and the main support mechanism is the feed-in premium (FIP). The French electricity market is structured conform to the EU legal and regulatory framework. The support for renewable technologies as solar PV, wind, biomass is already carried on through the capacity market mechanism. The National Regulatory Agency is in charge for the organization of the tenders [12].

Until 2016, support for renewable electricity production consisted of a purchase obligation on an open-ended basis or in the form of a call for tender. Both methods are very similar as they are open to all and are financed in the same way. They both enable operators of renewable electricity installations to benefit from a long-term purchase contract at a guaranteed price (generally 15 to 20 years). The main difference is that, in a call for tender, the electricity sale price is one of the elements making up the tenderer's bid, while for the open-ended method, a purchase price is set by the State for each type of installation. The tender procedure, which previously comprised a 'simplified' and an 'ordinary' procedure laid down by [13] Decree No 2002-1434 of 4 December 2002, was reformed in 2016. There is now only one type of procedure, meaning that the time between launching the call for tenders and the selection of successful applicants can be reduced. The procedure was introduced under [14] Decree No 2016-170 of 18 February 2016. Changes were made to the support scheme for renewable electricity production in 2016.

A new support scheme, the 'additional payment', was introduced, which will, in part, take the place of the purchase obligation (Figure 1). This additional payment consists of a premium paid to renewable electricity producers on top of the market price received for the sale of the electricity. The premium should help ensure that producers receive enough remuneration overall to cover the cost of running their installation while guaranteeing a normal return on invested capital. It is also allocated in two ways, namely on an openended basis or by tender.

The scheme chosen was an ex-post premium, calculated as the difference between a reference price set either by the State under an open-ended system or by the applicant under a call for tenders, and a market reference price calculated by the sector (e.g. average annual electricity spot price). If the market price is greater than the reference price, the producer is required to reimburse the difference [15]. 


\section{Solar PV in France's electricity sector}

France plans to install $30 \mathrm{GW}$ of solar photovoltaic between 2020 and 2035. The multiannual energy program (PPE) set the objective of achieving 10.2 GW in 2018. For 2023 this objective is set to $18.2-20.2 \mathrm{GW}$ [16].

Figure 2 illustrates the installed solar PV capacities in France's regions as reported by September 2018. The connected power of the solar PV park reached $8766 \mathrm{MW}$, almost 9-fold the level of 2010. This capacity represents more than $80 \%$ of the 2018 PPE objective. The highest additional capacity was seen in 2011 with 1768 MW. Since 2005 the deployment of solar PV in France took place with an average annual growth rate of $30 \%$. The current capacity corresponds to 418330 solar PV plants installed by end of September 2018. Most photovoltaic plants in France are of small-scale. More than 70\% (297523) of solar PV plants in France have a capacity less than $3 \mathrm{~kW}$ providing only $9 \%$ (801 MW) of the total installed capacity for this technology.

The French capacity market scheme for solar photovoltaic supports the installations with a capacity larger than $250 \mathrm{~kW}$. Between 2011 and 2018 the share of these installations in the total installed capacity increased from $39 \%$ to $53 \%$. The share of installations less than $3 \mathrm{~kW}$ more than halved whereas the share of projects with capacity 100 $\mathrm{kW}-250 \mathrm{~kW}$ dropped from $22 \%$ to $13 \%$. In meanwhile the share of the projects with capacity $36 \mathrm{~kW}-100 \mathrm{~kW}$ increased from $8.6 \%$ to $13.3 \%$ [17]. The support for solar PV in France increased by a factor of almost 12 between 20102018 , from $€ 0.25$ billion to nearly $€ 2.9$ billion [15]. In November 2018, the EU state aid approved the French scheme to support solar installations for electricity. The scheme has an indicative budget of $600 \mathrm{M} €$ for the deployment of $350 \mathrm{MW}$ additional capacity of innovative solar installations from $100 \mathrm{~kW}$ to $5 \mathrm{MW}$ [18].

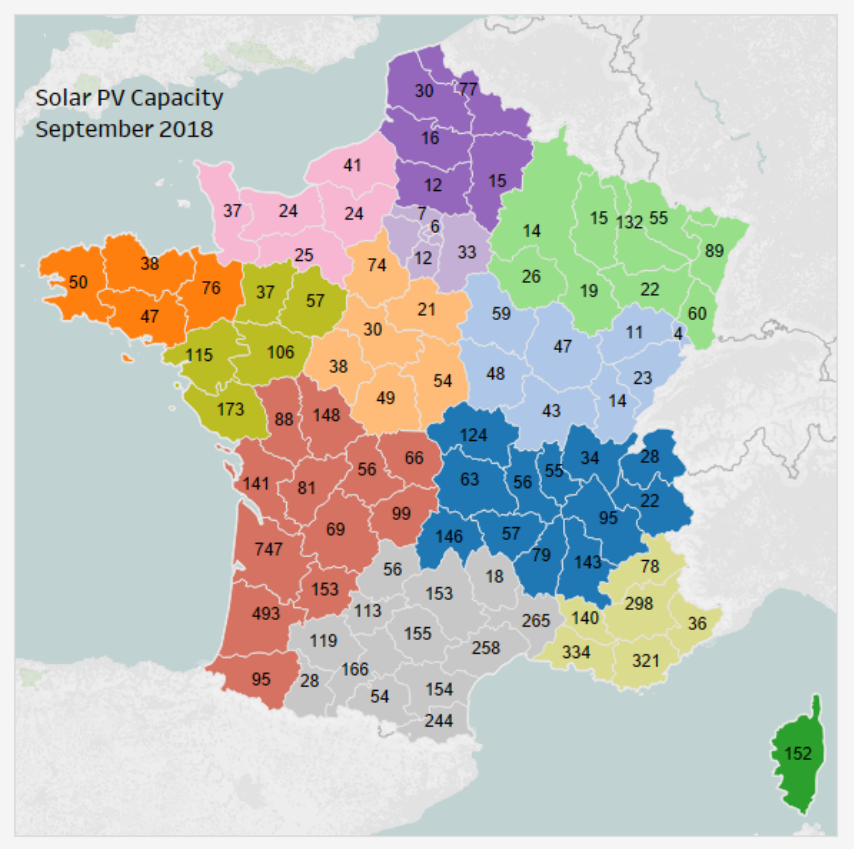

Fig. 2. Solar PV capacity (MW) in France by regions, September 2018

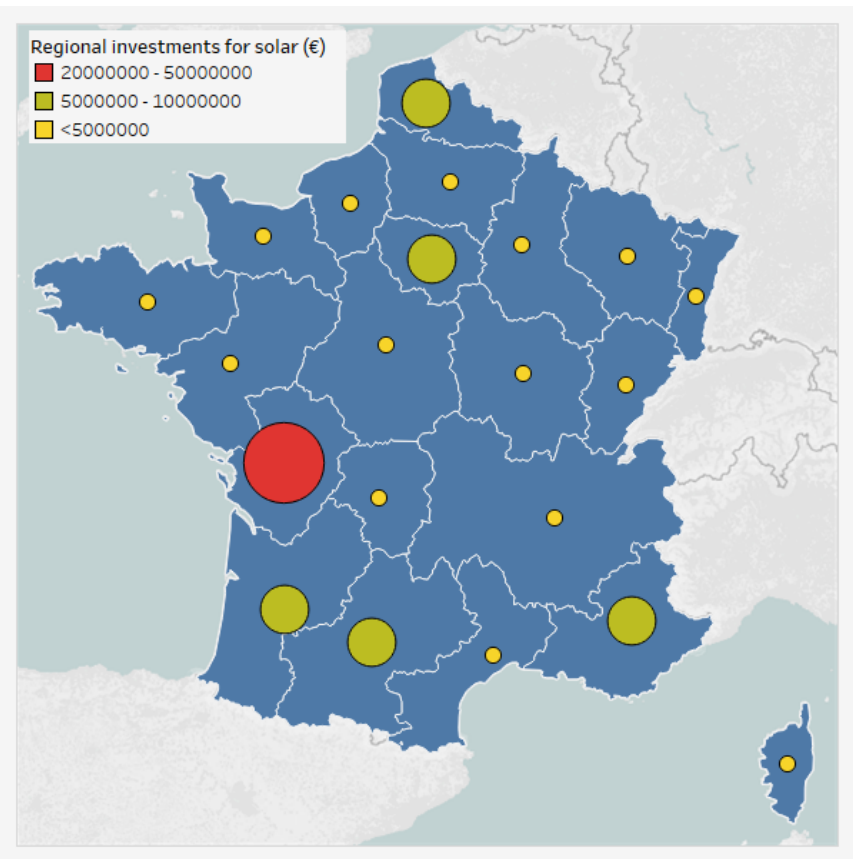

Fig. 3. Regional investments for solar PV from EU Cohesion Funds, 2007-2013

France has been one of the countries to have received high investments for solar through the EU Cohesion Policy Funds over period 2007-2013. A total of $1071 \mathrm{M} €(0.31 \%)$, were allocated to solar energy investments across the European regions over this period.

As shown in Figure 3 the main regions in France, in which were allocated the highest EU Cohesion Policy 20072013 investments for solar, were Nouvelle-Aquitaine, Occitanie, Provence-Alpes-Côte d'Azur, Île-de-France and Nord-Pas-de-Calais [19]

Number of patents for solar PV in France have reached 1781 in 2016 with the highest number of additions in 2010 $(+305)$. After this year the patents for solar PV in France decreased significantly [27]. Solar PV sector in France created 5200 jobs in 2016, contributing with 5\% to the EUwide employment for solar PV with a turnover at $€ 0.7$ billion [26].

\section{Tendering system for solar PV in France}

Table 1 shows the legislative framework of support schemes for solar PV projects in France. The tendering system is characterized by different categories of installations (small, medium or large) and types (rooftops, ground-mounted, in buildings). Pay-as-bid is being used as the standard price finding mechanism. The price has been always the main criteria for the selection of bids in a tender procedure. Other criteria such as environmental impacts, contribution to R\&D and/or the stage of the project development has played a role as well. Depending on the solar PV tender category, a significant number of documents were requested to the participants, as for example the ISOcertification [12]. Apart from past tenders for medium scale solar PV (2011 and 2013), financial prequalification's were requested for all tenders ranging from 30 to $100 € / \mathrm{kW}$. 
Table 1. Legislative framework for solar PV support schemes in France

\begin{tabular}{|l|l|l|r|}
\hline & & FIT & Capacity \\
\hline Act of 07.12.2010 & Tender & & X \\
\cline { 1 - 1 } Decree of 09.11.2016 & & & \\
\hline Act of 28.05.2016 & On demand & X & \\
\cline { 1 - 1 } Order of 09.05.2016 & & & \\
\hline
\end{tabular}

France set minimum bid prices for the more recently introduced tendering procedures for rooftop solar PV (42 $€ / \mathrm{MWh}$ for the last one, $50 € / \mathrm{MWh}$ initially), large scale solar PV and ground mounted solar PV installations (66 $€ / \mathrm{MWh}$ for the last one, $95 € / \mathrm{MWh}$ initially). Figure 4 shows how the solar PV projects average price and number of bids selected have changed in tendering system over period 20122017.

France do not charge any fee for participating in the tendering procedures. France foresees a reduction in support time in case of delayed realization of the solar PV installation. Throughout the tendering system, the guaranteed support time for solar PV installations is 20 years [12].

Before 2016, calls for tender were divided into two categories, i.e. building installations with a capacity of between 100 and $250 \mathrm{~kW}$ and (ground or building) installations with a capacity in excess of $250 \mathrm{~kW}$. Since 2016, calls for tender have been categorized differently and now distinguish between building installations (with a capacity of between $100 \mathrm{~kW}$ and $8 \mathrm{MW}$ ) and ground or canopy installations with a capacity of between $500 \mathrm{~kW}$ and 17 MW. For all calls for tenders launched since 2016, installations with a capacity of more than $500 \mathrm{~kW}$ have been eligible for support in the form of an additional payment, while those with a capacity of less than $500 \mathrm{~kW}$ have benefited from support in the form of purchase prices. The purchase price level for installations of less than $100 \mathrm{~kW}$ depends on their capacity and nature (sale of surplus or total). The price schedule can be found on the website of the French Energy Regulatory Commission [15].

Based on the requests for connection received during the preceding quarter, purchase prices are adjusted automatically each quarter. Prices fall by between $5 \%$ and $10 \%$ per year if the number of requests to connect installations is in keeping with the target trajectory (of approximately $350 \mathrm{MW} /$ year) [15].

According to the France's 2017 progress report [15] "three calls for tenders for developing building installations (with a capacity of between 100 and $250 \mathrm{~kW}$ ) were previously launched, following the simplified tender procedure set out in Decree No 2002-1434 of 4 December 2002 [13]:

A first call for tenders was launched on 1 August 2011 and closed in March 2013. This call for tenders covered a capacity of $300 \mathrm{MW}$ and ran for seven successive application periods.

A second call for tenders was launched on 26 March 2013 and closed in June 2014. This call for tenders covered a total capacity of $120 \mathrm{MW}$ and consisted of three application periods.
$>$ A third call for tenders was launched on 20 March 2015 and closed in June 2016. It covered a total capacity of $240 \mathrm{MW}$ and was divided into three application periods, each lasting four months".

A new call for tenders for building installations was launched in September 2016 following the new tender procedure and consisting of two categories of candidate, namely for capacity of between $100 \mathrm{~kW}$ and $500 \mathrm{~kW}$ and capacity of between $500 \mathrm{~kW}$ and $8 \mathrm{MW}$. The call for tenders initially covered a volume of $1350 \mathrm{MW}$, split over three years, with nine application periods of $150 \mathrm{MW}$ each. As of 2018 , volumes will be increased progressively up to $250 \mathrm{MW}$ for each application period. In the past, installations with a capacity in excess of $250 \mathrm{~kW}$ (both ground and building installations) received support under the ordinary call for tender's procedure [15].

According to the same progress report [15] "various criteria were used to select successful tenderers, i.e. price, environmental impact, industrial innovation, project timeframe, etc. Priority was given to areas of little competitive value, such as industrial wastelands, with a view to preserving biodiversity and agricultural and forestry uses. For this category three calls for tenders were launched:

$>$ A first call for tenders was launched on 15 September 2011 and closed on 3 August 2012. This call for tenders related to the construction of $450 \mathrm{MW}$ of new large-scale solar projects.

A second call for tenders was launched on 13 March 2013 and closed on 16 September 2013. It related to the construction of $400 \mathrm{MW}$ of photovoltaic projects, split equally between roof and ground systems.

A third call for tender was launched on 27 November 2014 and closed on 1 June 2015. This call for tenders related to the construction of $800 \mathrm{MW}$ of new large-scale solar projects".

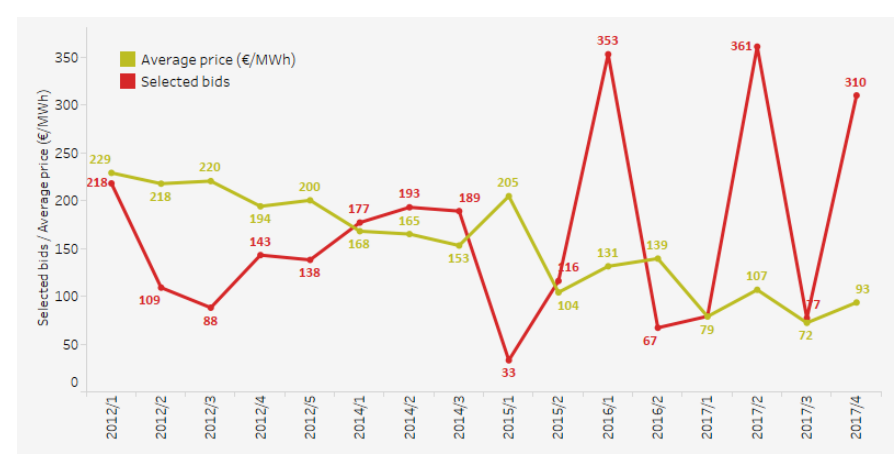

Fig. 4. Evolution of solar PV tenders' average price and bids selected (2012-2017) 
A call for tenders for ground installations was launched in August 2016 following the new tender procedure and consisting of three categories of candidate (capacity of between $500 \mathrm{~kW}$ and $5 \mathrm{MW}$, capacity of between 5 and 17 MW, carpark canopy installations with a capacity of between $500 \mathrm{~kW}$ and $10 \mathrm{MW}$ ). The call for tenders initially covered a volume of $3000 \mathrm{MW}$, split over three years, with six application periods of $500 \mathrm{MW}$ each. Two calls for tenders for self-consumption installations were launched in France after 2016:

$>$ A first call for tenders was launched in August 2016 for a volume of $40 \mathrm{MW}$ split between two application periods. Installations with a capacity of between 100 and 500 $\mathrm{kW}$ were eligible under the call for tenders. 72 projects were chosen for a weighted price of $40.88 € / \mathrm{MWh}$

A second call for tenders was launched in March 2017 for a period of three years, with a volume of $150 \mathrm{MW} / \mathrm{year}$ (three application periods per year). 62 projects were chosen for a weighted price of $19.35 € / \mathrm{MWh}$.

To enable an initial entry onto the market for innovative installations for which a demonstrator was already in place, a call for tenders was launched in March 2017 for developing innovative installations. The call for tenders consisted of three application periods of $70 \mathrm{MW}$ each (one application period per year)".

\section{Improvement of administrative procedures to remove regular and non-regular barriers for deployment of solar PV in France}

Article 15(1), (d) of the [6] states "simplified and less burdensome authorisation procedures, including a simplenotification procedure, are established for decentralised devices, and for producing and storing energy from renewable sources". Tendering system in France is a pointsbased criteria system for (i) price, (ii) simplified carbon evaluation, (iii) environmental impact and (iv) contribution to research and development with a maximum score of 30 points. The weighted score for price ranged between 12 $(>250 \mathrm{~kW})$ and $20(<250 \mathrm{~kW})[20]$. The first tenders for the medium-scale PV plants applied a prequalification criteria, requiring the bidder to be the owner of the building where the installation was planned to be built and a carbon dioxide $\left(\mathrm{CO}_{2}\right)$ assessment and a statement of recycling of the installation after its lifetime had to be submitted along with the bid. The $\mathrm{CO}_{2}$ assessment was contributing to $33 \%$ of the evaluation, whereas the price of the bid contributed to the rest. The support was paid for 20 years, and $80 \%$ of it was fix and $20 \%$ indexed. Many bids did not pass the prequalification criteria in the first year's rounds, which resulted in low competition level and higher prices than expected. The prequalification criteria were recognized to be challenging and the instructions for that insufficient. Therefore, the tender rules were re-designed for the next rounds and thus the two first rounds in 2013 cancelled [21].

Table 2 shows the evolution of administrative barriers for deployment of photovoltaics in France over period 20102016. Since 2012, facilities using renewable energy with a capacity less than $12 \mathrm{MW}$ were automatically authorized. In 2016, the levels below which an operating license does not have to be requested were raised to $50 \mathrm{MW}$ for all renewable sectors [15]. After 2016 the administrative procedure for applying to the Prefect for a purchase obligation certificate (CODOA), which was a prerequisite for all purchase contracts, has been abolished, thereby speeding up the implementation of projects [15].

Until 1 January 2018, a transition phase has been established during which a simple process of self-certification by the generator replaces the conformity certificate [22]. According to the new provisions the tender specifications are written by the Minister of the Economy then submitted to the CRE for approval, with just one month allocated to reach a decision. The specification must include several elements: the geographical area, the desired maximum power, a detailed description of the installations referred to and the conditions applicable to them, or an exhaustive list of the proposed evaluation criteria and their weighting or order of precedence. In relation to the criteria, the quantitative criteria represent at least $50 \%$ of the total weighting [22].

After the publication of the call at the CRE website to the applicants are given at least six months to send their applications. This timeframe is unchanged from the previous rules. Starting from the closing date for the submission of the application files, the CRE has between 15 days to four months to examine the bids received [22]. Previously, the CRE had two months as part of the accelerated procedure to examine the files and that there was no set regulatory time frame for the regular procedure [22]. The single environmental authorization reforms have taken place in successive steps: an initial three-year experimental phase governed by orders applying to several regions and a second phase during which the experiment was generalized to the entire national territory as a result of the "Macron law". The application of a single environmental authorization will be shortened processing times in 10 months versus 15 months for projects not benefiting from the single authorization [22].

Table 2. Existing regular and non-regular administrative barriers for deployment of solar PV in France

\begin{tabular}{|l|c|c|c|c|}
\hline & 2010 & 2012 & 2014 & 2016 \\
\hline One-stop-shop & present & present & not present & not present \\
\hline Online application & partly present & not present & not present & not present \\
\hline Maximum time limit for procedures & partly present & not present & not present & not present \\
\hline Automatic permission after deadline & present & present & present & present \\
\hline Facilitated procedures for small-scale projects (PV case) & not present & not present & not present & not present \\
\hline Identification of geographic sites & - & not present & not present & not present \\
\hline Single environmental application & present & present & present & partly present \\
\hline
\end{tabular}




\section{Measures ensuring transmission and distribution of electricity from solar PV in France}

In its $4^{\text {th }}$ Progress Report [15] France stated that "all producers of electricity from solar PV have a right of access to the grid that is guaranteed by law. If the system operator refuses to grant access, the regulator may impose a penalty, unless the refusal is justified by objective, non-discriminatory and open criteria. These criteria may be based only on imperatives connected with the proper performance of public service tasks and on technical grounds relating to grid safety and security and the quality of grid operation. Producers are entitled to obtain a technical and financial proposal for their connection under the conditions laid down in the system operator's technical reference documentation". The connection time shall not exceed 18 months for installations with installed power exceeding $3 \mathrm{kVA}$. For installations with power not exceeding this threshold, the maximum time of two months starting from acceptance of the connection offer is unchanged. The deadline begins from the date on which the network operator receives the signed connection offer and does not include the time needed for commissioning the generating installation [22].

\section{Trend of solar PV costs in Europe and in France}

Solar PV is now the cheapest source of electricity. The fall of prices for photovoltaics modules since 2009 has been significant in Europe. As shown in Figure 5 German crystalline module index price dropped by $82 \%$ over 2009 2017, to $0.45 € / \mathrm{kW}$ [20]. Solar PV module costs fell rapidly until 2013 but have experienced more modest cost reductions in recent years as photovoltaics module manufacturers made efforts to return profit margins to more sustainable levels and various trade disputes affected minimum prices in different markets. The weighted average Levelised Costs of Electricity (LCOE) of utility-scale solar PV fell 73\% over 2010 - 2017, to USD $0.10 / \mathrm{kWh}$. Increasingly, this technology is competing head-to-head with conventional power sources - and doing so without financial support [24].

Since 2010 the solar photovoltaic costs in France have seen a remarkable decrease. The utility-scale solar PV installed cost over period 2010-2017 saw a 77\% decrease. The average total installed costs of residential solar PV systems, during period Q2 2007-Q1 2017 decreased by 66\%.
The electricity costs of utility-scale solar PV in 2017 were $71 \%$ below the costs in 2010. The LCOE from residential solar PV systems, decreased by $61 \%$ over period Q2 2007-Q1 2017 [24].

\section{Indicative analysis of capacity market mechanism for solar PV in France}

The thresholds of $100 \mathrm{~kW}$ and $250 \mathrm{~kW}$ for 2011 solar PV tenders in France were chosen because: (i) the $250 \mathrm{~kW}$ threshold is the limit between low voltage and medium voltage in electricity network and corresponds to a connection threshold for (ERDF); (ii) the 2010 FIT scheme, distinguished the threshold of $250 \mathrm{~kW}$, and (iii) the facilities between 100 and $250 \mathrm{~kW}$ correspond to non-residential roofs category that exploded during 2006-2010 [20].

The average incentives of period 2011-2017 for solar $\mathrm{PV}$, given through the capacity market mechanism tended always to decrease, approaching as such to the wholesale electricity price. Banja \& Jégard [13] found that in 2017 the average price of calls for tenders almost halved compared with 2011. The introduction of separate tenders for different categories of solar PV projects lead to different price developments for these categories. Going through this analysis we found that since 2011 for ground mounted solar PV projects, the bid prices decreased by $72 \%$. For rooftop installations the decrease accounted for $60 \%$. For installations in buildings the price decreased by $60 \%$ (Figure 6).

After the re-design, the tendering system in France started been successful in ensuring an enough level of competition, which is estimated as the ratio between the bids volume vs the required volume. The level of competition is not constant and large variations can be observed. These variations can be due to the volume auctioned, number of rounds organized, the preparedness of the project developers, etc [12].

As shown in Figure 7 projects related mainly to groundmounted systems and innovative electricity generation facilities from solar PV had the highest level of competition. For ground mounted installation the level of competition was the highest. The tendered volume has been subscribed 12.4 times in 2013 where 188 dossiers with a capacity of 1240 MW where presented for a capacity of $100 \mathrm{MW}$. In 2014 the tender volume has been subscribed 10.7 times.

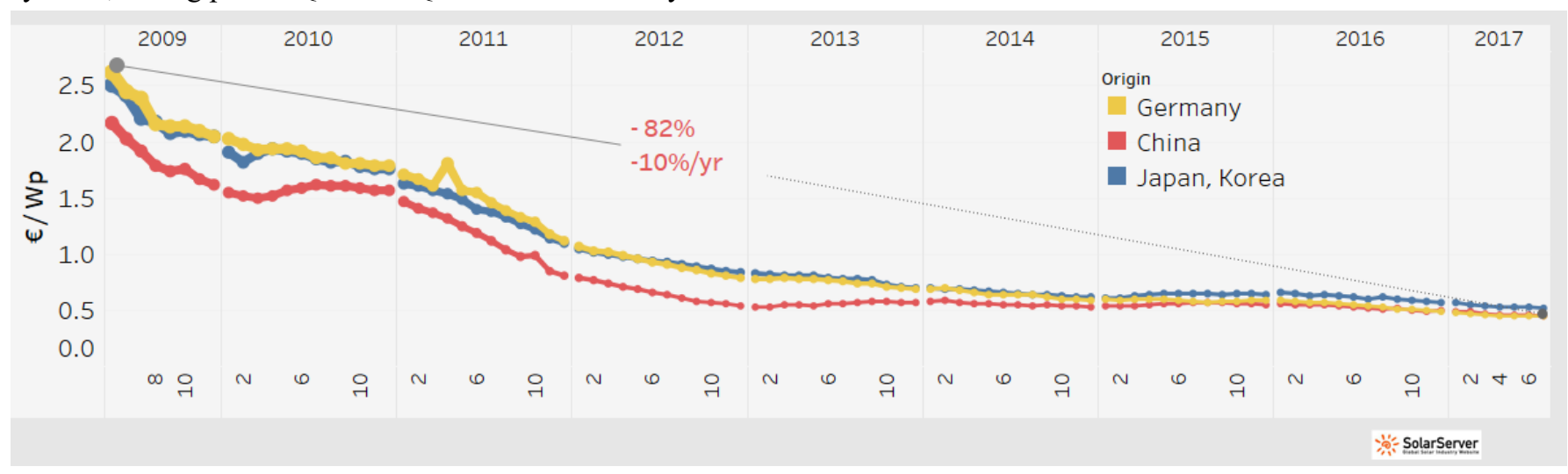

Fig. 5. Trend of crystalline module index price, (2009-2017) 


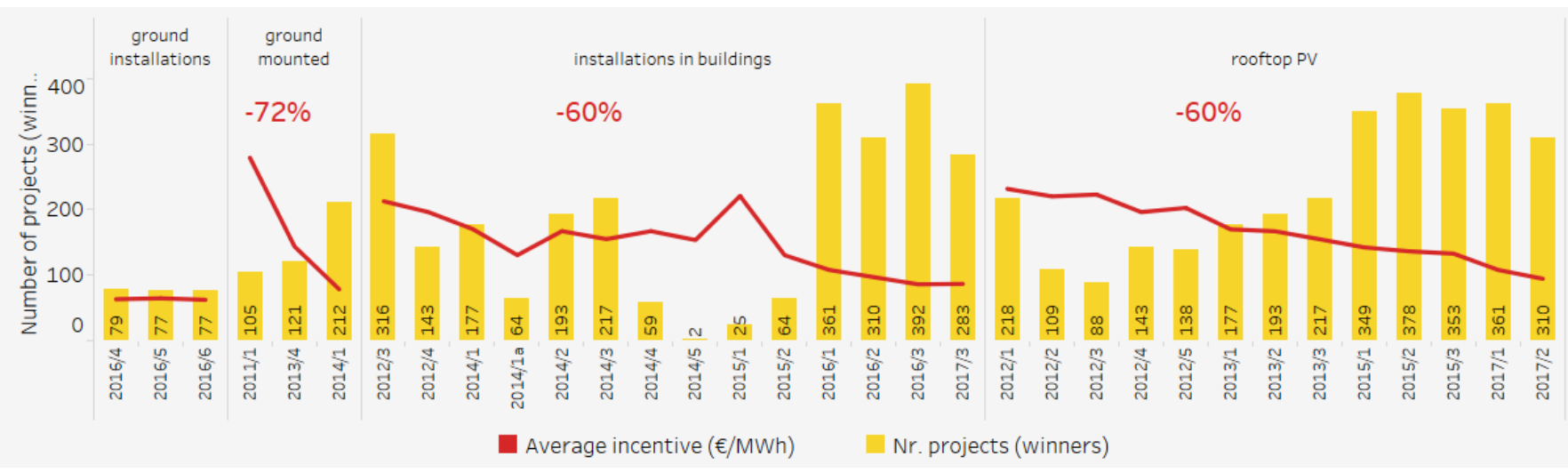

Fig. 6. Trend of average price \& number of projects in solar PV tenders in France, (2011-2017)

In 2015 the number of dossiers presented for the tender of overlay installations with capacity $>5 \mathrm{MW}$ was 137 with an overall capacity of $1332 \mathrm{MW}$. Only 12 projects for a capacity of $125 \mathrm{MW}$ were selected. Over 2016-2017 the ground-mounted tender saw a level of competition of 5.5 (among the highest) when 203 dossiers (742 MW) were presented for a required capacity of 135 MW. Only 33 projects were selected. The highest ratio between the price of dossiers and the average price of bids selected was found for ground-mounted projects during the tendering procedures over period 2016-2017. A correlation coefficient of 0.67 was found between the all capacity of dossiers submitted and all tender volume required, when a linear model with a coefficient of 3.5 was applied.

A large number of candidates competed for a small share of requred bid capacity in the calls for tenders for solar photovoltaic in France over period 2011-2017. Nealy 3000 was the number of projects that were presented in the calls for tenders organised between 2012 and 2014. Only in 2014, nealy half of these candidates participated at the calls for tenders that were characterised by the lowest ratio of winning bids versus the submitted dossiers. Over 2012-2014 almost 1300 contracts for solar PV were given. This number equals to almost half of contracts given over period 2011-2017. 12months was the time between the appeal and the date in which the tender was organized. The majority of calls for tender were developed in more than 1 period. 2011 was the year with the largest number of periods and the smallest fraction of capacity of bid [17].
According to [11] only few data are available for the evaluation of realization rate of tendering system in France. Tenders carried out for different PV categories in 2011 showed realization rate between $68 \%$ and $95 \%$ and for the 2013 round between $73 \%$ and $93 \%$.

\section{Conclusions}

This paper aims to analyse the dynamics of the solar PV French policy over period 2011-2017. The analysis described here shows some interesting results on how the capacity market mechanism is implemented in France to support the deployment of solar PV.

$>$ The largest additional installed capacity of solar PV in France was observed after 2010 when the French policy support for this technology start moving towards capacity market mechanism.

$>$ The decrease of average support level for solar PV through tendering system and the increase of the number of large-scale projects in the calls for tender, the additional capacity of solar PV in France has decreased after the maximum reached in 2011;

Tendering system for solar PV is set more as a technology-specific system. France has introduced tendering procedures for different categories of PV projects, such as ground mounted $\mathrm{PV}$, rooftop $\mathrm{PV}$, carport $\mathrm{PV}$ and/ or Concentrated Solar Power (CSP);

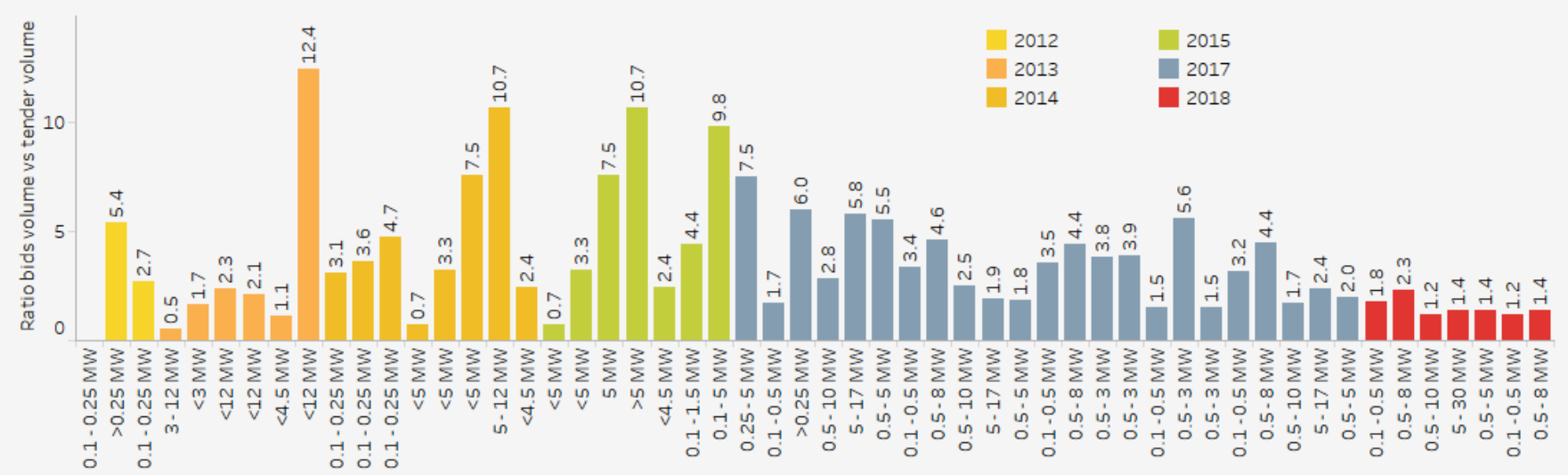

Fig. 7. Level of competition in solar PV tendering system in France, (2011-2017) 
The shift towards the capacity market mechanism has been accompanied by accelerated cost reductions in the solar sector. Over a period of 7 years the utility-scale solar PV installed costs decreased in average by $11 \%$ each year. For residential solar PV systems, the decrease of installing costs took place by $6.6 \%$ yearly in average terms over a period of 10 years;

The decrease in support prices for solar PV is observed from one tender to another. Even that this decrease does not show the effectiveness of the tendering system, since other external factors (e.g. cost of capital and raw material, regulatory changes, strategic behaviour) have influence on the outcome of the tender, it shows that France has created a favourable set of organisational structures, rules and informal norms to support this technology. It reflects also the decrease over time of the costs for solar PV projects;

$>$ Tendering system for solar PV in France is characterized by a high level of competition especially for ground-mounted systems. Project prices for these systems decreased in average terms by $12 \%$ yearly over the period under analysis. The highest level of competition is observed in tenders organised between 2013 and 2015;

The analysis showed that for each MW capacity solar $\mathrm{PV}$ required $3.5 \mathrm{MW}$ were offered by the participants in calls for tender.

Despite the improvements in the administrative procedures to remove the regular and non-regular barriers, a significant number of documents are already subject of permitting procedures for solar PV, depending also from the category of the project.

$>$ The latest solar PV tenders in France have attracted many small-scale producers, but it is needed these tenders to be simplified in respect to simplicity of design, online application, financial guarantees, complicated prequalification criteria, in order to allow them to be successful

\section{References}

[1] Aktas Z.A., (2015), "A Review and comparison of renewable energy strategies or policies of some countries", International Conference on Renewable Energy Research and Application, ICRERA 2015, Palermo, Italy

[2] Di Dio V., Favuzza S., La Cascia D., Massaro F., Zizzo G., (2013), "The evolution of the FIT mechanism in Italy for PV systems: A critical analysis", International Conference on Renewable Energy Research and Application, ICRERA 2013, Madrid, Spain

[3] Borghesi A., Milano M., (2014), "Multi-agent simulator of incentive influence on PV adoption", International Conference on Renewable Energy Research and Application, ICRERA 2014, Milwaukee, USA

[4] EC, "European Commission guidance for the design of renewables support schemes", SWD (2013)-439, https://ec.europa.eu/energy/sites/ener/files/documents/co $\underline{\text { m_2013 public intervention_swd04_en.pdf }}$
(Staff Working Document, Last Accessed on April 9, 2019)

[5] EC, "Guidelines on State aid for environmental protection and energy 2014-2020" (2014/C 200/01), https://eurlex.europa.eu/legalcontent/EN/TXT/PDF/?uri=CELEX:52014XC0628(01)\& from=IT (Last Accessed on April 9, 2019)

[6] Directive 2018/2001 of the European Parliament and of the Council of 11 December 2018 "on the promotion of the use of energy from renewable energy sources (recast), https://eur-lex.europa.eu/legalcontent/EN/TXT/PDF/?uri=CELEX:32018L2001\&from= EN (Last Accessed on April 9, 2019)

[7] Jäger-Waldau, A., “PV Status Report 2017”, EUR 28817 EN, Publications Office of the European Union, Luxembourg, 2017, ISBN 978-92-79-74071-8, doi:10.2760/452611, JRC108105, https://ec.europa.eu/jrc/en/publication/eur-scientific-andtechnical-research-reports/pv-status-report-2017 (Report, Last Accessed on April 9, 2019)

[8] Law No. 2000/108, 10th February, http://welfi.hespul.org/cdwelfi/fr en/pdf/Law n 2000108.pdf (Legislation, Last Accessed on April 9, 2019)

[9] France renewable energy progress reports 2011, 2013, 2015, https://ec.europa.eu/energy/en/topics/renewableenergy/progress-reports (Report, Last Accessed on April 9, 2019)

[10] Law No. 2010/1488 of December 2010, (Legislation)

[11] https://uk.practicallaw.thomsonreuters.com (last accessed May 2018)

[12] CEER (2018), "Tendering procedures for RES in Europe: State of play and first lessons learnt", https://www.ceer.eu/documents/104400/-/-/167af87c5472-230b-4a19-f68042d58ea8 (Report, Last Accessed on April 9, 2019)

[13] Decree No 2002-1434 of 4 December 2002, https://www.legifrance.gouv.fr/affichTexte.do?cidTexte $=$ JORFTEXT000000782766\&categorieLien=cid (Legislation)

[14] Decree No 2016-170 of 18 February 2016, https://www.legifrance.gouv.fr/affichTexte.do?cidTexte =JORFTEXT000032080513\&categorieLien=id (Legislation, Last Accessed on April 9, 2019)

[15] France Progress Report 2017, https:/ec.europa.eu/energy/en/topics/renewableenergy/progress-reports (Report, Last Accessed on April 9, 2019)

[16] https://www.ecologiquesolidaire.gouv.fr/programmations-pluriannuelleslenergie-ppe (last accessed December 2018, Last Accessed on April 9, 2019)

[17] Banja M., Jégard M., (2018), Support for solar photovoltaics in France- a shift towards capacity market mechanism. International Conference on Renewable 
Energy Research and Application, ICRERA 2018, Paris, France

[18] EC Press Release 27 November 2018, http://europa.eu/rapid/press-release_IP-18-6582_en.htm (Last accessed December 2018)

[19] Castilla C. P., Silva F. B. and Lavalle C., (2016), An assessment of the regional potential for solar power generation in EU-28, Energy Policy Vol.88, pp.86-89, (Article)

[20] Grau Th., (2014), Comparison of Feed-in Tariffs and Tenders to Remunerate Solar Power Generation, https://www.diw.de/documents/publikationen/73/diw 0 1.c.437464.de/dp1363.pdf (Discussion Papers), Last Accessed on April 9, 2019

[21] Held A., Ragwitz M., ISI F., Gephart M., Visser E. and Klessmann C. "Design features of support schemes for renewable electricity", January 27, 2014, https://ec.europa.eu/energy/sites/ener/files/documents/2 014 design features of support schemes.pdf (Report)

[22] Fornacciari M. and Verrier J., (2017), "Renewable Energy: The new regulatory landscape in France", Dentons, May 22, 2017, http://www.mondaq.com/france/x/596378/Renewables/ Renewable+Energy+The+New+Regulatory+Landscape + In+France (Report, Last Accessed on April 9, 2019)
[23] https://www.solarserver.com (last accessed June 2018)

[24] IRENA, (2018), Renewable Power Generation Costs in 2017, https://www.irena.org//media/Files/IRENA/Agency/Publication/2018/Jan/IRE NA 2017 Power Costs 2018.pdf (Report, Last Accessed on April 9, 2019)

[25] France national renewable energy action plan (NREAP)., 2010, https://ec.europa.eu/energy/en/topics/renewableenergy/national-renewable-energy-action-plans-2020 (Report, Last Accessed on April 9, 2019)

[26] EurObser'ER, (2017), The state of renewable energies in Europe, https://www.eurobserver.org/pdf/2016/EurObservER-Annual-Overview-2016EN.pdf (Report, Last Accessed on April 9, 2019)

[27] http://resourceirena.irena.org/gateway/dashboard/?topic $=1019 \&$ subTopic $=1058$ (last accessed June 2018)

[28] Öko-Institut, E3-Modelling. Observ'ER, COWI, CESR, RENAC, Study on Technical Assistance in Realisation of the 2016 Report on Renewable Energy, https://ec.europa.eu/energy/en/studies/study-technicalassistance-realisation-2016-report-renewable-energypreparation-renewable-0, (Study ENER/C1/2014-688, Last Accessed on April 9, 2019) 